Journal of Homosexuality, 61:1667-1686, 2014

Copyright (c) Taylor \& Francis Group, LLC

ISSN: 0091-8369 print/1540-3602 online

DOI: $10.1080 / 00918369.2014 .951253$

\title{
University Students' Attitudes Toward Same-Sex Parenting and Gay and Lesbian Rights in Portugal
}

\author{
PEDRO ALEXANDRE COSTA, PhD \\ University of Beira Interior \& Psychology \& Health Research Unit (UIPES), ISPA-IU, \\ Lisbon, Portugal \\ RUTE ALMEIDA, BS, CÁTIA ANSELMO, BS, \\ and ANDRÉ FERREIRA, BS \\ Psychology \& Health Research Unit (UIPES), ISPA-IU, Lisbon, Portugal \\ HENRIQUE PEREIRA, PhD \\ University of Beira Interior \& Psychology \& Health Research Unit (UIPES), ISPA-IU, \\ Lisbon, Portugal \\ ISABEL LEAL, PhD \\ Psychology \& Health Research Unit (UIPES), ISPA-IU, Lisbon, Portugal
}

\begin{abstract}
The purpose of this study was to explore university students' attitudes toward same-sex parenting and toward gay and lesbian rights. A total of 292 participants, aged between 18 and 27 $(M=21)$ responded to a questionnaire measuring attitudes toward parenting by gay men and lesbians, gay and lesbian rights, and beliefs about the etiology of homosexuality. Results revealed that the majority of students were against gay and lesbian parenting, gay and lesbian equal rights, and believed that homosexuality has a social/environmental basis. It was found that sexual prejudice is bighly prevalent in Portuguese university students, and implications of these findings are discussed.
\end{abstract}

KEYWORDS same-sex parenting, gay and lesbian rights, bomosexuality, university students, attitudes, etiology, homonegativity

Address correspondence to Pedro Alexandre Costa, Psychology \& Health Research Unit (UIPES), ISPA-IU, Rua Jardim do Tabaco, 43, 1149-041 Lisbon, Portugal. E-mail: pcosta@ispa.pt 


\section{INTRODUCTION}

The U.S. Census Bureau estimated that over 150,000 same-sex couples were raising children under the age of 18 , and that over 270,000 children were growing up with two same-sex parents and over 540,000 children with one gay father or one lesbian mother (U.S. Census Bureau, 2003). Other community estimates revealed that approximately $20 \%$ of lesbian women and $11 \%$ of gay men were parents (Bryant \& Demian, 1994), estimating that the number of children being raised by a lesbian, gay, or bisexual parent was between six and 14 million (Patterson \& Friel, 2000; Ryan \& Martin, 2000). In Europe, however, the immense diversity in Lesbian, Gay, Bisexual, and Transgender (LGBT) families, mostly due to the different legal and social contexts, makes it more difficult to estimate the number of children and parents in LGBT families. Community studies have revealed that, for example, between 5\% and $8 \%$ of Italian gay men and lesbians and between 3\% and 8\% of Portuguese gay men and lesbians are raising children (Costa, Pereira, \& Leal, in press; Lelleri, Prati, \& Pietrantoni, 2008).

The first impetus for the study of lesbian- and gay-led families came from a concern with the developmental outcomes of children being raised in these families (Patterson, 1992, 1994). Both in the United States and throughout Europe there have been several legal custody cases in which parents' sexual orientation is used as a motive for denying parental rights to gay and lesbian parents.

Although the first studies of gay parents started in the late 1980s, it was only close to the turn of the century that the number of studies in this research area started to proliferate (Patterson, 2006), overall concluding that parental sexual orientation does not negatively influence a child's development and that gay men and lesbians are as fit parents as heterosexuals (Anderssen, Amlie, \& Ytteroy, 2002; Crowl, Ahn, \& Baker, 2008; Tasker, 2005). Similar conclusions were echoed by both the American Psychological Association (Paige, 2005) and the American Association of Pediatrics (Perrin \& Committee on Psychosocial Aspects of Child and Family Health, 2002), among other international scientific associations. Nevertheless, societal attitudes toward gay and lesbian parenting do not seem to mirror these scientific conclusions.

Attitudes toward gay and lesbian families are founded on attitudes toward gay, lesbian, and bisexual people themselves. Literature has revealed that negative attitudes toward homosexual people are common and widespread in Western societies (Kite \& Whitley, 1996), showing that people who hold more negative attitudes toward homosexual people are more likely to hold sexist attitudes and to adhere to traditional gender roles, to have a more traditional view of the nuclear family, to be more religious, and to identify with a conservative political ideology (Brown \& Henriquez, 2008; Costa \& Davies, 2012; Davies, 2004; Herek, 2000a; Lingiardi, Falanga, \& 
D'Augelli, 2005; Nagoshi et al., 2008; Sotelo, 2000; Steffens \& Wagner, 2004). It has also been observed that sex plays a significant role on negative attitudes toward homosexual people. Men hold more negative perceptions of homosexual people than women, and more intensely toward gay men than toward lesbians (Costa \& Davies, 2012; Herek, 2000b; Lingiardi, Falanga, \& D'Augelli, 2005; Sotelo, 2000; Steffens \& Wagner, 2004).

Another key variable in predicting negative attitudes toward gay men and lesbians is how people perceive the controllability of homosexual orientation and behaviors. The developmental origins of homosexuality can be seen as either controllable, thus changeable (social, environmental, individual choice), or not controllable and thus unchangeable (biological or genetic basis).

The body of research on this particular association revealed that people whose beliefs are of a controllability of homosexuality hold more negative attitudes toward gay men and lesbians, as well as less support to gay men's and lesbians' rights and gay and lesbian-relevant legislation (Haider-Markel \& Joslyn, 2008; Hewitt \& Moore, 2002; Smith, Zanotti, Axelton, \& Saucier, 2011; Whitley, 1990; Wood \& Bartkowski, 2004). It is noteworthy that the beliefs about the origins of homosexuality seem to be rooted in people's religious affiliation and political ideology (e.g., Haider-Markel \& Joslyn, 2008). These attitudes thus foster negative attitudes toward gay men and lesbians as parents (Crawford \& Solliday, 1996; McLeod, Crawford, \& Zechmeister, 1999).

Although attitudes toward gay and lesbian parenthood are part of a general attitude toward gay and lesbian rights, the topic of parenthood is more likely to have an affective basis, as a reaction toward gay and lesbian people, rather than a cognitive response to their civil rights. The most common arguments against gay men and lesbians as parents are either based on judgments of parents as immoral or unfit due to their sexual orientation or based on the negative effects that these parents have on child development (Clarke, 2001).

Research about people's attitudes toward gay and lesbian parents is still scarce and has not been following the increase in scientific inquiry into family and child development in gay- and lesbian-headed families. Earlier studies have found that university students held low to medium levels of negative reactions toward gay men and lesbians, but more negative perceptions of gay and lesbian-headed families (Crawford \& Solliday, 1996). The authors also reported that not only students tended to grant custody significantly less to same-sex couples, but also they justified with judgments of instability in same-sex couples.

Similar results were found in North American psychology students (Fraser, Fish, \& Mckenzie, 1995; King \& Black, 1999; Money \& Cain, 1997). However, even in studies where no differences in judgments between samesex and opposite-sex couples were found, participants still revealed concern 
with the possibility of the children being harassed in school and being exposed to more difficulties in their daily life (Bliss \& Harris, 1999; McLeod, Crawford, \& Zechmeister, 1999).

In contrast, a more recent study with Australian social work students revealed that the participants held a positive attitude toward gay men and lesbians as parents and showed low levels of negative attitudes toward gay men and lesbians (Camilleri \& Ryan, 2006). None of these studies have tried to evaluate the relation between these attitudes and demographic variables, such as religious beliefs and political inclination, attitudes toward gay and lesbian rights, or beliefs about origins of homosexuality that has been shown to be highly important in predicting negative reactions toward gay men and lesbians.

\section{The Portuguese Context}

In recent years, there have been a few political and legislative initiatives regarding LGBT rights. After the legal recognition of same-sex couples in civil partnerships in 2001 (Bill 7/2001), it was only in 2010 that same-sex couples were allowed to marry with the same rights as opposite-sex couples (Bill 9/2010). However, this same law that allowed same-sex couples to get married explicitly precluded these couples from adopting or to accessing assisted reproductive technology, and it was not approved without controversy. After the majority of votes obtained in the Portuguese Parliament by the center and left-wing political parties, the president of Portugal (former prime minister from a conservative party) decided to convene a press conference to inform the public of his displeased endorsement of the law. After the Supreme Court verdict stating that same-sex marriage was not unconstitutional, his endorsement was due to the existence of more pressing economic matters in the country that needed undivided attention, adding that he recognized that this matter was not sufficiently debated within civil society. In fact, according to a European Human Rights Commission report (2011), Portuguese citizens were mostly opposed to several LGBT rights, namely same-sex marriage and same-sex parenting.

Recent changes in the Portuguese government, with the election of a coalition of right-wing political parties in 2011, fueled opposite actions and gave rise to civil platforms committed to revoking same-sex marriage law, as well as laws designed to protect other social rights such as reproductive rights, family planning, and gender/sex identity transitioning.

The few scientific and empirical studies about levels of prejudice toward gay and lesbian people in Portugal show that negative attitudes are prevalent among adolescents (Costa \& Davies, 2012), and they document the existence of negative attitudes toward gay and lesbian parenting (Costa et al., 2013; Xavier, Mendes, Martins, \& Fernandes, 2011). Moreover, recent actions promoted by left-wing parties together with LGBT advocacy organizations 
have tried to approve a law allowing same-sex couples to adopt a child and to access reproductive technology and recognizing co-parents in same-sex families. Not only have these actions been rejected by the majority of conservative parliamentarians, but they have also been received with disdain. On a legal report from the Portuguese Lawyers Association regarding the legitimacy of a law that recognizes co-parents in same-sex families, it reads:

The right of the child to be adopted implies that the adoption respects the principle of natural family, i.e., a family constituted by a father (man) and a mother (woman) and not by a man playing a mother or by a woman playing a father. (Pinto, 2012, p. 2)

Although North American research has been prolific in developing measures to evaluate attitudes and beliefs toward gay and lesbian issues, there are few measures developed or adapted to the European context. Even more so, considering the different social, cultural, and economic differences among European countries, attitude measures need to be adjusted to each country's specific context. The purpose of this study was, thus, to develop measures to evaluate attitudes toward gay and lesbian parenting, gay and lesbian rights, and the influence of demographic variables and of beliefs about the origins of homosexuality in these attitudes in Portugal.

\section{METHOD}

\section{Participants}

The sample consisted of 292 university students from Lisbon, Portugal, aged between 18 and 27 years ( $M=21, S D=2), 54 \%$ males and $46 \%$ females. The vast majority of participants identified as heterosexual (92\%), 39\% identified as Catholic, $43 \%$ as atheist, and $11 \%$ as spiritual but with no religious affiliation. From the 112 participants who identified as Catholics, less than one third attended church more often than once or twice a year, 30\% once or twice a year, and $40 \%$ only on religious holidays and ceremonies. Regarding political orientation, 25\% identified as left-wing (or liberal), 35\% as center (moderates), 33\% as right-wing (or conservatives), and $7 \%$ did not respond. Regarding subject of study, the majority of participants were studying engineering (52\%), followed by psychology (27\%), law (5\%), languages and literature (4\%), and social sciences (3\%).

\section{Measures}

Participants responded to a questionnaire booklet designed for this study. The questionnaire booklet consisted of basic demographic questions, the Attitudes Toward Gay and Lesbian Parenting Scale, the Attitudes Toward 
Gay and Lesbian Civil Rights Scale, and a few questions regarding beliefs about the etiology of homosexuality.

With regard to the measures used in this study, all are currently under development as part of a larger study about attitudes toward gay and lesbian parenting in Portugal. The Attitudes Toward Gay and Lesbian Parenting Scale consists of 11 items intended to measure participants' beliefs about gay men and lesbians as parents. Six items represent the most common beliefs about the negative impact of gay and lesbian parents on child development and about gay men and lesbians as unfit parents. These items were loosely based on arguments identified by Clarke (2001) in the United Kingdom and arguments identified by Costa and colleagues in Portugal (Costa et al., 2013). Another five items represent a more positive view of gay- and lesbianparented families based on evidence found in literature about the differences between children in lesbian- and gay-led families and in heterosexual-led families. The Attitudes Toward Gay and Lesbian Civil Rights Scale consists of eight items and was developed based on the most common topics currently under discussion in Portugal, in face of recent legislative initiatives regarding same-sex unions and same-sex parenting. Finally, the beliefs about the etiology of homosexuality were measured using six questions addressing the most common beliefs and assumptions about the developmental origins of homosexuality. Although this is not a scale, the questions in this measure are expected to be significantly correlated.

\section{Procedure}

Participants were approached on university campuses in Lisbon, Portugal, by three researchers and asked to participate in a study about attitudes toward gay and lesbian parenting in Portugal. The questionnaires were distributed to students from six different faculties, and they were asked to fill in a questionnaire and to return it to the researcher. Participants were also informed of the study's aims and of how to fill in and return the questionnaire, and they were asked for their written participation consent. All participants who agreed to take part in this study returned their questionnaires. This study conformed to ethical research guidelines set by the Portuguese Psychological Society (OPP).

\section{RESULTS}

\section{Principal Component Analysis}

\section{Attitudes Toward Gay and Lesbian Parenting Scale}

Final solution revealed three factors with eigenvalues greater than 1.00, accounting for $56 \%$ of explained variance. An examination of the scree plot 
and factor loadings revealed that two factors should be retained and these were rotated to varimax criteria. Factor 1 comprised six items that pertained to negative attitudes toward gay and lesbian parenting, thus named "Negative perceptions of gay and lesbian parenting" (AHPN). This factor accounted for $29 \%$ of explained variance with a coefficient $\alpha$ of .78. Factor 2 comprised five items that reflected a positive view of gay and lesbian parenting, and it was named "Perception of benefits of gay and lesbian parenting" (AHPP). This second factor accounted for a total of $17 \%$ of explained variance and revealed a coefficient $\alpha$ of .57 (Table 1).

\section{Attitudes Toward Gay and Lesbian Civil Rights SCale}

The final solution revealed two factors with eigenvalues greater than 1.00, accounting for 59\% of explained variance, although there was evidence that only one factor should be retained (AHR). This factor comprised all eight items accounting for $45 \%$ of explained variance, with a coefficient $\alpha$ of .77 (Table 2).

\section{Attitudes Toward Gay and Lesbian Parenting}

The majority of the university students were against gay and lesbian parenting. When evaluating the arguments behind these attitudes, moral and religious motivations were highlighted; 92\% agreed with the statement "Gay and lesbian parents do not care about children's best interests" and 84\% with "Gay men and lesbians should not have children because it is a sin." A smaller but significant percentage of the participants based their arguments on concerns about the children, such as the likelihood of them being harassed by peers or being confused about their sexuality.

Significant differences in negative perceptions of gay and lesbian parenting were found for religious affiliation, political ideology, sex, and subject of study. Young men, compared to young women, were generally more negative toward gay and lesbian parenting $(t(290)=3.18, p=.001)$. In particular, arguments against lesbian and gay parenting based on sin $(t(290)$ $=2.96, p<.01)$, children's best interests $(t(290)=3.10, p<.01)$ confusion about sexuality $(t(290)=2.61, p=.01)$, and unnatural $(t(290)=3.01$, $p<.01)$ were significantly more endorsed by men than by women. In contrast, women agreed significantly more with the statement that there are homosexuals with the emotional availability to be parents $(t(290)=2.19$, $p<.05)$.

Catholic people scored significantly higher than atheist people on negative attitudes toward gay and lesbian parenting $(t(238)=3.81, p<.001)$. Catholics were more likely to agree with statements such as "Gay and lesbians should not have children because it is a $\sin "(t(238)=2.84, p<.01)$, 


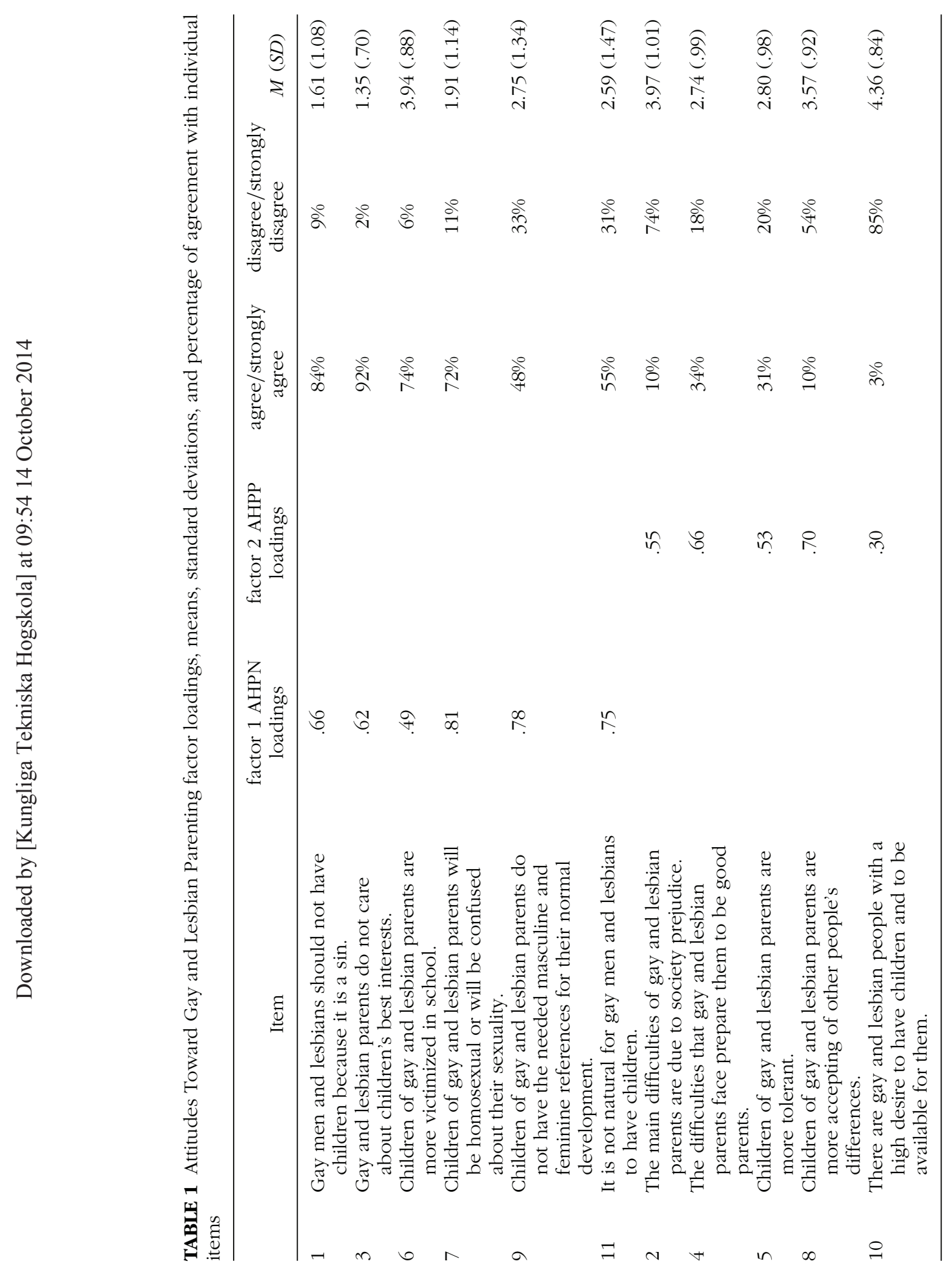




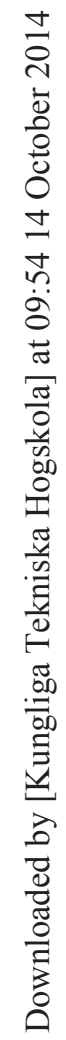

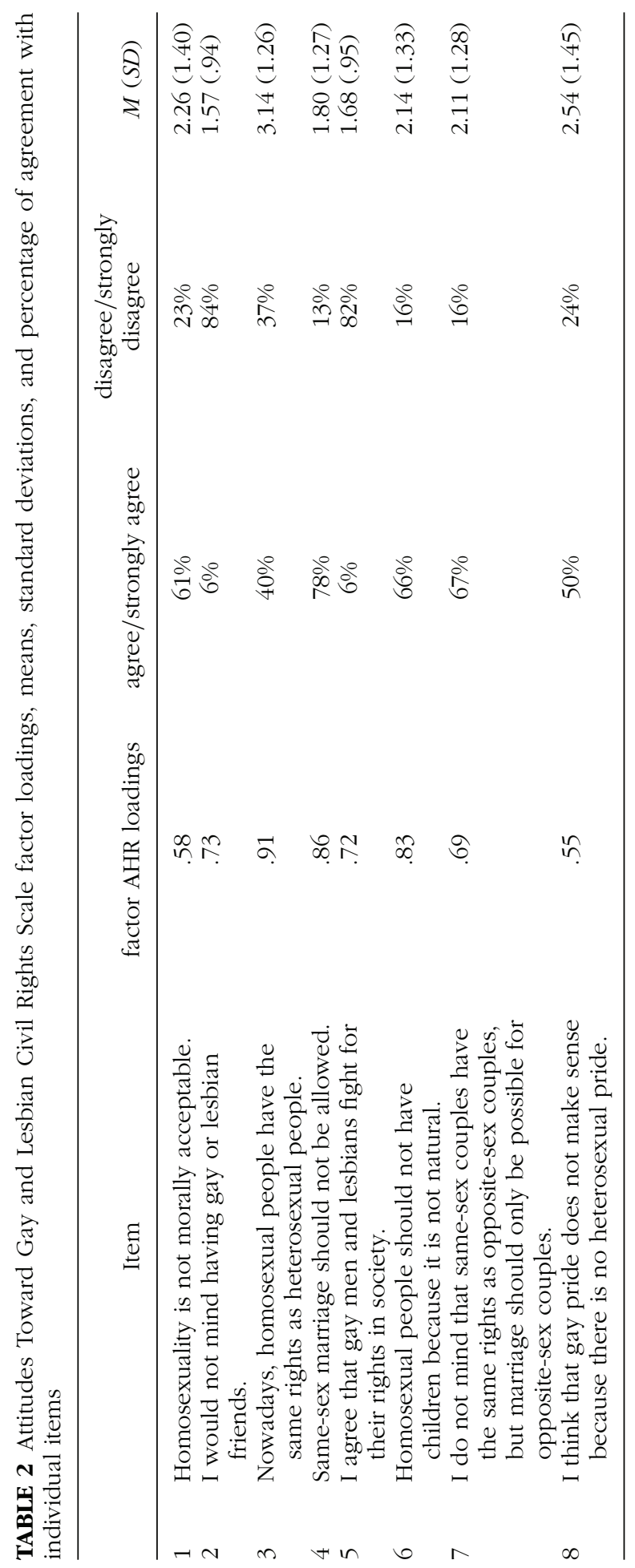

1675 
"Gay and lesbians do not care about children's best interests $(t(238)=1.97$, $p=.05)$, "Children of gay and lesbian parents will be homosexuals" ( $t(238)$ $=2.92, p<.05$ ), "Children of gay and lesbian parents do not have the needed masculine and feminine references for their normal development" $(t(238)=5.08, p<.001)$, and "It is not natural for gay men and lesbians to have children" $(t(238)=1.99, p<.05)$.

Participants with a right-wing political inclination were more likely to agree with statements such as "Gay and lesbian parents do not care about children's best interests" $(t(167)=2.40, p<.05)$, "Children of gay and lesbian parents will be homosexuals" $(t(167)=3.04, p<.01)$, and "Children of gay and lesbian parents do not have the needed masculine and feminine references for their normal development" $(t(167)=3.87, p<.001)$, compared to people with a left-wing inclination, and held more negative perceptions overall $(t(167)=3.44, p=.001)$.

Group differences were also found for major subject of study. Engineering students were more likely than psychology students to endorse negative statements that characterize gay and lesbian parenting as a sin $(t(231)=2.25, p<.05)$, as unnatural $(t(231)=2.23, p<.05)$, as not caring for children's best interests $(t(231)=2.10, p<.05)$, and that their children will later be homosexuals themselves $(t(231)=2.50, p=.01)$. When evaluating the global scores on each subscale, engineering students held more negative perceptions of gay and lesbian parenting $(t(231)=2.58, p<.01)$, whereas psychology students scored higher on the perception of benefits of gay and lesbian parenting $(t(231)=2.77, p<.01)$.

\section{Attitudes Toward Gay and Lesbian Civil Rights}

The vast majority of the participants were against gay and lesbian equal rights in general, and against same-sex marriage (78\%) and same-sex parenting (66\%) in particular. Seventy-eight percent of the participants agreed with the statement "Same-sex marriage should not be allowed," and 67\% stated that "I do not mind that same-sex couples have the same-rights as opposite-sex couples, but marriage should only be possible for opposite-sex couples." This latter statement was included to evaluate if participants who did not support same-sex marriage would still acknowledge same-sex couples' rights, and this was not supported, which reinforces the high level of prejudice found in this sample.

Gender differences were found in relation to gay and lesbian civil rights $(t(290)=4.15, p<.001)$. Young men were more likely than young women to be uncomfortable with having gay or lesbian friends $(t(290)=5.96, p<$ $.001)$ and with same-sex marriage $(t(290)=4.27, p<.001)$, and to disagree with gay and lesbian people fighting for their rights $(t(290)=3.05, p<$ $.01)$ and to have children $(t(290)=3.58, p<.001)$. 
Catholic people were also found to hold more negative attitudes toward gay and lesbian rights than atheist people $(t(238)=4.37, p<.001)$, judging homosexuality as immoral $(t(238)=4.46, p<.001)$, to be against same-sex marriage $(t(238)=3.53, p=.001)$, same-sex couples' rights $(t(238)=4.08$, $p<.001)$, same-sex parenting $(t(238)=3.64, p<.001)$, and against gay and lesbian people fighting for their rights $(t(238)=3.62, p<.001)$.

Similarly, right-wing participants were more likely to be against samesex marriage $(t(167)=4.03, p<.001)$, same-sex couples' rights $(t(167)$ $=3.64, p<.001)$, same-sex parenting $(t(167)=3.54, p=.001)$, lesbian and gay people fighting for their rights $(t(167)=2.29, p<.05)$, judging homosexuality as morally unacceptable $(t(167)=3.84, p<.001)$, and agreeing with the statement "Gay pride does not make sense because there is no heterosexual pride" $(t(167=3.13, p<.01)$, and more negative overall $(t(167)=4.85, p<.001)$.

Engineering students were more likely to endorse negative attitudes toward gay and lesbian rights than psychology students $(t(231)=3.35$, $p=.001)$ and statements such as "Same-sex marriage should not be allowed" $(t(231)=2.27, p<.05)$, "Homosexual people should not have children because it is not natural" $(t(231)=3.07, p<.01)$, "Marriage should only be possible for opposite-sex couples" $(t(231)=3.07, p<.01)$, and disagreeing with gay men and lesbians fighting for their rights $(t(231)=2.27, p<.05)$.

\section{Beliefs About Origins of Homosexuality}

Most of the participants showed a number of misconceptions about the developmental origins of homosexuality. Almost three quarters of the sample stated that children of gay and lesbians parents are likely to develop a homosexual orientation, with the underlying assumption that sexual orientation can be learned. In fact, $56 \%$ of the participants agreed that homosexuality is a choice, and $80 \%$ that it can be learned in contact with homosexual persons. Moreover, $87 \%$ of the participants believed that homosexuality is a mental illness, and less than one third of the sample agreed that homosexuality is genetic and therefore not changeable (Table 3).

Gender differences were also found on the beliefs about the origins of homosexuality. Young men were significantly more likely than young women to believe that "Homosexuality is a choice" $(t(290)=2.79, p<$ $.01)$, that "Parents play an important role on the development of their children's sexual orientation" $(t(290)=3.34, p=.001)$, that "Homosexuality is learned in contact with homosexual people" $(t(290)=2.23, p<.05)$, that "Homosexuality is a mental illness" $(t(290)=4.80, p<.001)$, and to disagree that "Homosexuality is as natural as heterosexuality" $(t(290)=4.61$, $p<.001)$.

Similarly, Catholic people were more likely to sustain environmental causes of homosexuality such as being a choice $(t(238)=2.56, p=.01)$, 


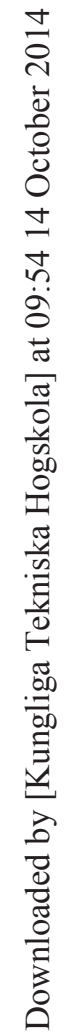

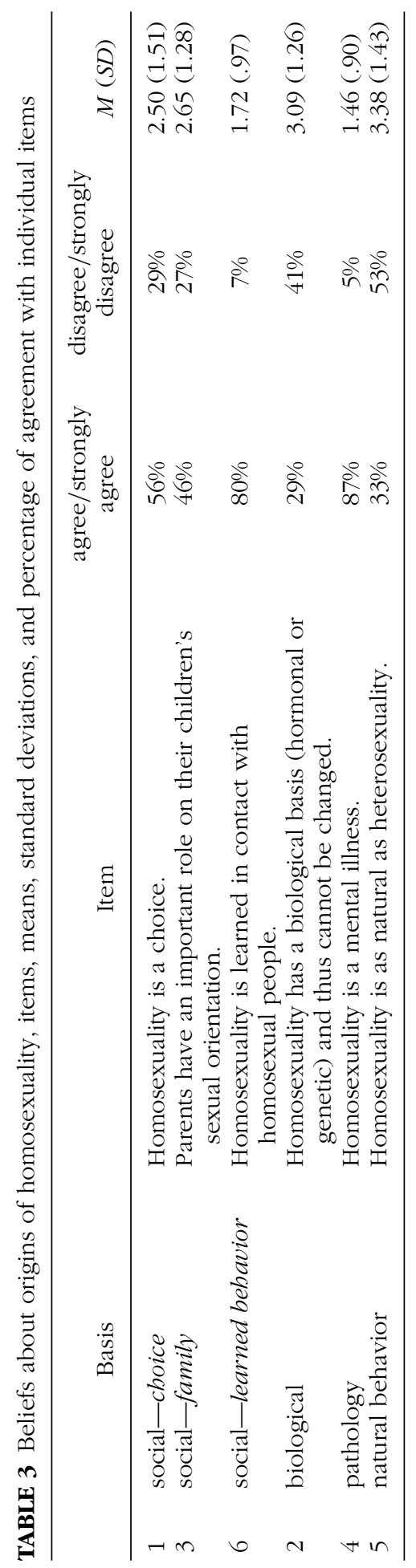

1678 
being learned $(t(238)=2.30, p<.05)$, being a mental illness $(t(238)=2.69$, $p<.01)$, and being an unnatural expression of sexuality $(t(238)=3.29, p=$ .001) than atheist people.

Right-wing people were not significantly more likely to endorse an environmental basis for homosexuality than left-wing people but were significantly more in agreement with statements such as "Homosexuality is a mental illness" $(t(167)=3.01, p<.01)$, it is not as natural as heterosexuality $(t(167)=4.00, p<.001)$, and it is a choice $(t(167)=3.04, p<.01)$.

Psychology students were more likely than engineering students to disagree with the statement "Homosexuality is a mental illness" $(t(231)=3.08$, $p<.01$ ), and to agree with the statement "Homosexuality is as natural as heterosexuality" $(t(231)=3.50, p=.001)$.

\section{Correlation Between Attitude Measures}

To investigate the association between the scales that measure attitudes toward gay and lesbian parenting, toward gay and lesbian rights, and beliefs about the basis of homosexuality, Pearson's bivariate correlations were performed. As shown in Table 4, there was a strong association between negative attitudes toward gay and lesbian parenting and gay and lesbian rights. These associations were also associated, although not as strongly, with beliefs about a social/environmental origin of homosexuality, as well as with homosexuality as a mental illness. In contrast, the perception of benefits of gay and lesbian parenting was negatively associated with negative attitudes toward gay and lesbian rights, with the belief of homosexuality as a learned behavior, and as a mental illness. The perception of benefits was also weakly positively associated with the belief of a biological basis for homosexuality.

\section{DISCUSSION}

The present study aimed to evaluate Portuguese university students' support for gay and lesbian parenting and gay and lesbian civil rights. The scales used in this study are currently under development as no other measure exists in the Portuguese scientific literature; therefore, these results should be read as exploratory. As expected, the underlying two-factor structure of the Attitudes Toward Gay and Lesbian Parenting Scale was supported, measuring both negative perceptions of gay and lesbian families and perception of benefits of these families. This multidimensional scale was developed to measure the most common negative and positive perceptions of gay and lesbian parenting that would allow exploring inconsistencies in evaluating these families, and the negative relation between the two factors seems to confirm this assumption. 


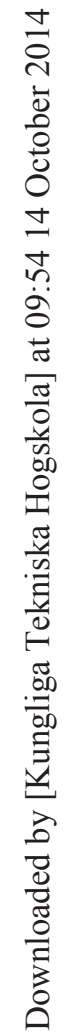

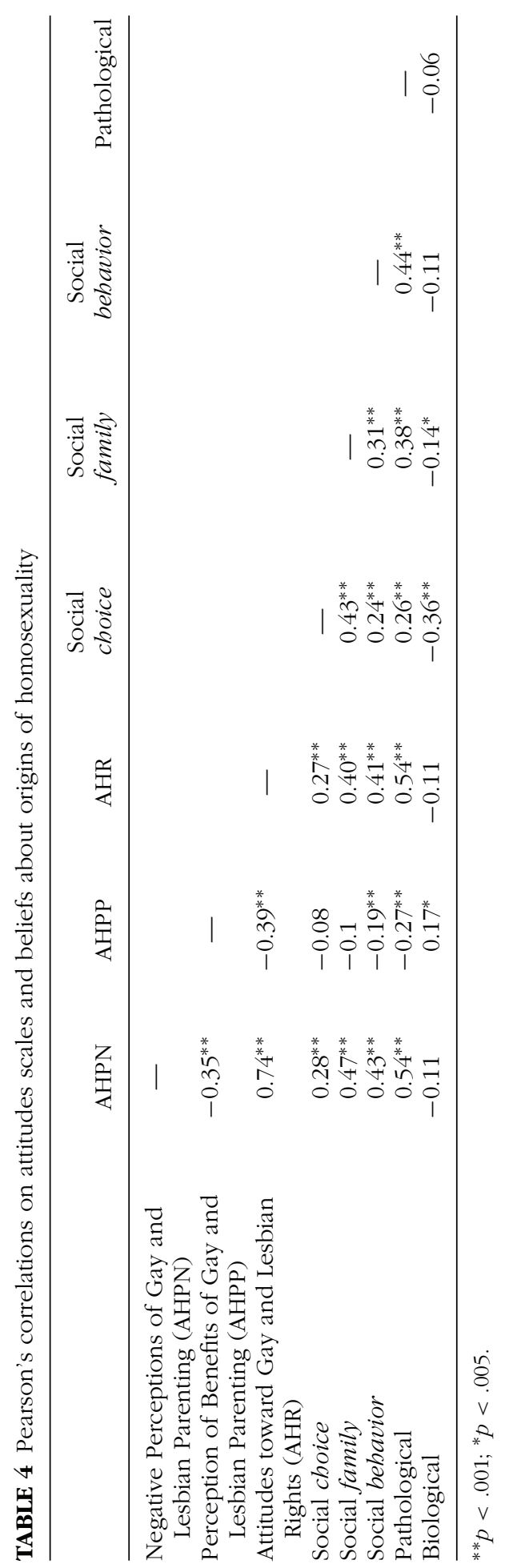

1680 
The items on the Attitudes Toward Gay and Lesbian Civil Rights Scale were developed in face of recent legislative and societal changes in Portugal, in which same-sex marriage and same-sex parenting have been under dispute. As expected, the more negative a participant's attitude toward gay and lesbian civil rights, the more likely they would hold negative perceptions of gay and lesbian parenting. The strength of these scales, we believe, rely on the fact that the items measure endorsed arguments and values, which provide a more accurate and reliable portrait of people's attitudes toward gay and lesbian issues.

Although these scales were developed in Portugal with the purpose of being culturally sensitive, we were able to find similar patterns in this study's participants' attitudes toward gay and lesbian rights to those reported in the international literature. Males are usually more negative than females toward gay men, lesbians, and gay and lesbian rights (Davies, 2004; Ellis, Kitzinger, \& Wilkinson, 2003; Herek, 2000b; Kite \& Whitley, 1996; Whitley, 2001), and this is also true among young male university students (Brown \& Henriquez, 2008; LaMar \& Kite, 1998). Homophobic respondents are also more likely to be religiously affiliated and politically conservative (or right-wing; Brown \& Henriquez, 2008; Nagoshi et al., 2008; Schulte \& Battle, 2004; Whitley, 2008). The same trend was found in the few research papers on attitudes toward gay and lesbian parenting, which were mostly conducted with university students (Camilleri \& Ryan, 2006; Crawford \& Solliday, 1996; Fraser, Fish, \& Mackenzie, 1995; McLeod, Crawford, \& Zechmeister, 1997). However, these studies used a quasi-experimental design with the use of case vignettes as opposed to survey designs.

Recent studies have also highlighted the importance of the beliefs about the origins of homosexuality in explaining attitudes toward gay men and lesbians. The belief of a social or environmental basis for homosexuality is strongly related to negative attitudes toward gay men and lesbians, and to a lesser support of gay and lesbian rights (Haslam \& Levy, 2006; Smith, Zanotti, Axelton, \& Saucier, 2011; Wood \& Bartkowski, 2004). This relation was also found in the present study, and although beliefs about social and environmental basis of homosexuality were only weakly correlated with attitudes toward gay and lesbian parenting and toward gay and lesbian civil rights, the belief that homosexuality is a mental illness was not only highly prevalent but also more strongly correlated with these attitudes. As such, these beliefs may not be direct predictors of attitudes toward gay and lesbian rights, but more closely linked to negative affective reactions toward lesbian and gay men, i.e., homophobia (Costa \& Davies, 2012; Smith et al., 2011).

As Haider-Markel and Joslyn (2008, p. 307) argued, "Perceiving responsibility for the behavior naturally evokes questions about the morality of homosexuality and support for policies that favor conventional relationship follows." Considering that these beliefs are strong predictors of attitudes 
toward gay men and lesbians, it is not surprising that psychology students, who are more likely to be familiar with research on the development of sexual orientation, held more positive views of gay and lesbian rights and gay and lesbian parenting. Although this hypothesis is supported by North American evidence that psychologists hold somewhat affirming attitudes toward gay men and lesbians and their families (Choi, Thul, Berenhaut, Suerken, \& Norris, 2006; Crawford, McLeod, Zamboni, \& Jordan, 1999), a survey with British psychology students did not report strong negative attitudes toward lesbian and gay individuals but showed that students were not supportive of gay and lesbian access to legal marriage and parenting (Ellis, Kitzinger, \& Wilkinson, 2003).

In Portugal, the number of studies about attitudes toward gay men and lesbians in general, or about attitudes toward gay and lesbian parenting in particular, are very scarce. A study about high school students' attitudes toward gay, lesbian, and transgender people showed that negative attitudes were generally prevalent, and that young men had higher levels of homophobia and transphobia than young women (Costa \& Davies, 2012). In relation to attitudes toward gay and lesbian parenting, other studies revealed the existence of negative attitudes toward these families among university students (Xavier, Mendes, Martins, \& Fernandes, 2011) and among the general population (Costa et al., 2013). Although only one of these studies measured the level of negativity by means of a questionnaire survey, it showed that the majority of participants were indeed against extending parenting rights to gay men and lesbians (Xavier et al., 2011).

As previously stated, recent legislative initiatives in Portugal made it possible for same-sex couples to marry in equal circumstances to opposite-sex couples. However, the same legislation introduced a ban for same-sex couples to adopt or to have access to assisted reproductive technologies, and these topics are still highly controversial. According to a recent European Human Rights Commission report (2011), 81\% of Portuguese people were against same-sex couples adopting a child, and $71 \%$ were opposed to allowing same-sex couples to marry. In that sense, and although homophobic behaviors are not very frequently reported, Portuguese people are, in general, still reluctant in granting equal rights to gay men and lesbians.

These results are cause for concern. Not only were most university students against gay and lesbian parenting, but they were also against gay and lesbian rights and held misconceptions and prejudicial beliefs about the origins of homosexuality. Our initial assumption was that university students, in the face of recent social and legal developments in Portugal and throughout Europe, would be more informed and comfortable with gay and lesbian issues. Instead, our results showed a rather opposite picture. It seems likely that homonegative beliefs may be more highly prevalent than we anticipated. 
This study is not without limitations. Although the scales in this study held acceptable to good internal reliabilities, more work is needed to validate these measures with other more established measures, such as the Affective Reactions Toward Gay Men and Lesbians (Costa \& Davies, 2012; Davies, 2004) or the Attitudes Toward Lesbians and Gay Men Scale (Herek, 1994). Moreover, the questions measuring the beliefs about the etiology of homosexuality should be further developed into a scale that could tap into more specific arguments and beliefs.

Another limitation regards the sample used in this study, which was a young and educated sample of students, and although it makes a contribution to the understanding of university students' attitudes, the results cannot be generalized to the Portuguese population. Future endeavors should be made to use larger and more representative samples, not just to evaluate the prevalence of negative attitudes, but more specifically to explore the causal relations between sociodemographic and psychological attributes and negative attitudes toward gay men and lesbians and gay and lesbian rights.

\section{CONCLUSION}

This study helped to cast light on the prevalence of prejudicial attitudes toward gay men and lesbians in Portugal, paving the way for the development of research in this field. Although these results were exploratory in its scope, the development of these new socially and culturally relevant scales that measure attitudes toward same-sex parenting, gay and lesbian rights, and etiology beliefs are instrumental for the advancement of empirical research on LGBT issues. We found that the beliefs about the origins of homosexuality, support for gay and lesbian rights, political orientation, religious affiliation, and attitudes toward same-sex parenting were closely related, and we suggest that future research should extend these findings by investigating causal relations between them. In particular, etiology beliefs may play a major role in predicting attitudes toward gay men and lesbians, and the ways in which these etiology beliefs are formed are extremely important for the understanding of sexual prejudice, as well as for the development of policies to confront it. We believe that educating people, particularly youth, about LGBT issues and about the developmental origins of homosexuality is extremely important in order to promote change in attitudes toward them.

In conclusion, these results indicated that while Portugal's recent legislative changes promoted equality for LGBT people, university students hold negative attitudes toward gay and lesbian rights and still hold highly prejudicial attitudes toward them. The continuity of study into the causal attributions and development of such attitudes is extremely important to create social change that reflects these legal changes. 


\section{REFERENCES}

Anderssen, N., Amlie, C., \& Ytteroy, E. A. (2002). Outcomes for children with lesbian or gay parents: A review of studies from 1978 to 2000. Scandinavian Journal of Psychology, 43, 335-351.

Bliss, G. K., \& Harris, M. B. (1999). Teachers' views of students with gay or lesbian parents. Journal of Gay, Lesbian, and Bisexual Identity, 4, 149-171.

Brown, M. J., \& Henriquez, E. (2008). Socio-demographic predictors of attitudes towards gays and lesbians. Individual Differences Research, 6, 193-202.

Bryant, A. S., \& Demian (1994). Relationship characteristics of American gay and lesbian couples: Findings from a national survey. Journal of Gay \& Lesbian Social Services, 1, 101-117.

Camilleri, P., \& Ryan, M. (2006). Social work students' attitudes toward homosexuality and their knowledge and attitudes toward homosexual parenting as an alternative family unit: An Australian study. Social Work Education, 25, 288-304.

Choi, H., Thul, C. A., Berenhaut, K. S., Suerken, C. K., \& Norris, J. L. (2006). Survey of school psychologists' attitudes, feelings, and exposure to gay and lesbian parents and their children. Journal of Applied School Psychology, 22, 87-107.

Clarke, V. (2001). What about the children? Arguments against lesbian and gay parenting. Women's Studies International Forum, 24, 555-570.

Commissioner for Human Rights. (2011). Discrimination on grounds of sexual orientation and gender identity in Europe. Strasbourg: Council of Europe Publishing.

Costa, P. A., Caldeira, S., Fernandes, I., Rita, C., Pereira, H., \& Leal, I. (2013). Atitudes da população Portuguesa em relação à homoparentalidade [Portuguese attitudes toward homosexual parenting]. Psicologia: Reflexão e Crítica, 26, 790-798.

Costa, P. A., \& Davies, M. (2012). Portuguese adolescents' attitudes toward sexual minorities: Transphobia, homophobia and gender role beliefs. Journal of Homosexuality, 59, 1424-1442.

Costa, P. A., Pereira, H., \& Leal, I. (in press). Social, psychological and demographic data of LGBT people in Portugal. Manuscript submitted for publication.

Crawford, I., McLeod, A., Zamboni, B., \& Jordan, M. (1999). Psychologists' attitudes toward gay and lesbian parenting. Professional Psychology: Research and Practice, 30, 394-401.

Crawford, I., \& Solliday, E. (1996). The attitudes of undergraduate college students toward gay parenting. Journal of Homosexuality, 30(4), 63-77.

Crowl, A., Ahn, S., \& Baker, J. (2008). A meta-analysis of developmental outcomes for children of same-sex and heterosexual parents. Journal of GLBT Family Studies, 4, 385-407.

Davies, M. (2004). Correlates of negative attitudes toward gay men: Sexism, male role norms, and male sexuality. Journal of Sex Research, 41, 259-266.

Ellis, S., Kitzinger, C., \& Wilkinson, S. (2003). Attitudes towards lesbians and gay men and support for lesbian and gay human rights among psychology students. Journal of Homosexuality, 44(1), 121-138.

Fraser, I., Fish, T., \& Mackenzie, T. (1995). Reactions to child custody decisions involving homosexual and heterosexual parents. Canadian Journal of Behavioral Science, 27, 52-63. 
Haider-Markel, D. P., \& Joslyn, M. R. (2008). Beliefs about the origins of homosexuality and support for gay rights. Public Opinion Quarterly, 72, 291-310.

Haslam, N., \& Levy, S. R. (2006). Essentialist beliefs about homosexuality: Structure and implications for prejudice. Personality and Social Psychology Bulletin, 32, $471-485$.

Herek, G. M. (1994). Assessing heterosexuals' attitudes toward lesbians and gay men: A review of empirical research with the ATLG scale. In B. Greene \& G. W. Herek (Eds.), Lesbian and gay psychology: Theory, research, and clinical applications. Psychological perspectives on lesbian and gay issues (vol 1; pp. 206-228). Thousand Oaks, CA: Sage Publications.

Herek, G. M. (2000a). The psychology of sexual prejudice. Current Directions in Psychological Science, 9(1), 19-22.

Herek, G. M. (2000b). Sexual prejudice and gender: do heterosexuals' attitudes toward lesbian and gay men differ? Journal of Social Issues, 56, 251-266.

Hewitt, E., \& Moore, L. (2002). The role of lay theories about the etiologies of homosexuality in attitudes toward lesbians and gay men. Journal of Lesbian Studies, 6(3-4), 59-72.

King, B. R., \& Black, K. N. (1999). College students' perceptual stigmatization of the children of lesbian mothers. American Journal of Orthopsychiatry, 69, 220-227.

Kite, M. E., \& Whitley, B. E. (1996). Sex differences in attitudes toward homosexual persons, behaviors, and civil rights: A meta-analysis. Personality and Social Psychology Bulletin, 22, 336-353.

LaMar, L., \& Kite, M. (1998). Sex differences in attitudes toward gay men and lesbians: A multidimensional perspective. Journal of Sex Research, 35, 189-196.

Lelleri, R., Prati, G., \& Pietrantoni, L. (2004). Omogenitorialità: I risultati di una ricerca Italiana [Homoparenting: Results from an Italian survey]. Difesa Sociale, 4(8), 71-83.

Lingiardi, V., Falanga, S., \& D'Augelli, A. R. (2005). The evaluation of homophobia in an Italian sample. Archives of Sexual Behavior, 34(1), 81-93.

McLeod, A. C., Crawford, I., \& Zechmeister, J. (1999). Heterosexual undergraduates' attitudes toward gay fathers and their children. Journal of Psychology \& Human Sexuality, 11(1), 43-62.

Money, D. W., \& Cain, R. E. (1997). Preservice elementary teachers' attitudes toward gay and lesbian parenting. Journal of School Health, 67(6), 236-241.

Nagoshi, J. L., Adams, K. A., Terrell, H. K., Hill, E. D., Brzuzy, S., \& Nagoshi, C. T. (2008). Gender differences in the correlates of homophobia and transphobia. Sex Roles, 59, 521-531.

Paige, R. U. (2005). Sexual orientation, parents, \& children: Proceedings of the American Psychological Association, Incorporated. Minutes of the meeting of the Council of Representatives July 28 and 30, 2004, Honolulu, HI. Retrieved from http://www.apa.org/about/governance/council/policy/parenting.aspx

Patterson, C. J. (1992). Children of lesbian and gay parents. Child Development, 63, $1025-1042$.

Patterson, C. J. (1994). Lesbian and gay families. Current Directions in Psychological Science, 3(2), 62-64.

Patterson, C. J. (2006). Children of lesbian and gay parents. Current Directions in Psychological Science, 15(5), 241-244. 
Patterson, C. J., \& Friel, L. V. (2000). Sexual orientation and fertility. In G. Bentley \& N. Mascie-Taylor (Eds.), Infertility in the modern world: Biosocial perspectives (pp. 238-260). Cambridge: Cambridge University Press.

Perrin, E. C., \& Committee on Psychosocial Aspects of Child and Family Health. (2002). Technical report: coparent or second-parent adoption by same-sex parents. Pediatrics, 109, 341-344.

Pinto, A. M. (2012). Parecer da Ordem dos Advogados (sobre o projecto de lei $n^{\circ}$ 278/XII/ $1^{a}$ (PS) consagrando a possibilidade de co-adopção pelo cônjuge ou unido de facto do mesmo sexo) [Report from the Portuguese Lawyers Association]. Retrieved from http://www.oa.pt/Conteudos/Artigos/ detalhe_artigo.aspx?idc $=58$ idsc $=115187$ \&ida $=124343$

Ryan, D., \& Martin, A. (2000). Lesbian, gay, bisexual, and transgender parents in the school systems. School Psychology Review, 29, 207-216.

Schulte, L. J., \& Battle, J. (2004). The relative importance of ethnicity and religion in predicting attitudes towards gays and lesbians. Journal of Homosexuality, 47(2), $127-142$.

Smith, S. J., Zanotti, D. C., Axelton, A. M., \& Saucier, D. A. (2011). Individuals' beliefs about the etiology of same-sex sexual orientation. Journal of Homosexuality, 58, $1110-1131$.

Sotelo, M. J. (2000). Political tolerance among adolescents towards homosexuals in Spain. Journal of Homosexuality, 39(1), 95-105.

Steffens, M. C., \& Wagner, C. (2004). Attitudes toward lesbians, gay men, bisexual women, and bisexual men in Germany. Journal of Sex Research, 41, 137-149.

Tasker, F. (2005). Lesbian mothers, gay fathers, and their children: A review. Journal of Developmental \& Behavioral Pediatrics, 26, 224-240.

U.S. Census Bureau. (2003). Married couple and unmarried-partner households: 2000 -Census 2000 special reports. Retrieved from http://www.census.gov/ prod/2003pubs/censr-5.pdf

Xavier, P., Mendes, F., Martins, E., \& Fernandes, R. (2011). A homoparentalidade na perspectiva de estudantes do ensino superior [Homoparenting from a university students' perspective]. Proceedings of the XI Congresso Internacional Galego-Portugués de Psicopedagoxía. Retrieved from repositório.ipv.pt/handle/ $10400.19 / 982$

Whitley, B. E. (1990). The relationship of heterosexuals' attributions for the causes of homosexuality to attitudes toward lesbians and gay men. Personality and Social Psychology Bulletin, 16, 369-377.

Wood, F. B., \& Bartkowski, J. R. (2004). Attribution style and public policy attitudes toward gay rights. Social Science Quarterly, 85, 58-74 